\title{
Nutrients Distribution and Trophic Status Classification in Coastal Waters of Pulau Pasaran, Lampung
}

\author{
B Putri $^{1, *}$ M R Nur Huda ${ }^{1}$ H Yulianto ${ }^{1}$ I G Yudha ${ }^{1}$ N M Noor ${ }^{2}$ M Ali ${ }^{1}$
}

\author{
${ }^{1}$ Department of Fisheries and Marine Science,Universitas Lampung, Bandar Lampung, Indonesia \\ ${ }^{2}$ Department of Aquaculture, State Polytechnic of Lampung, Bandar Lampung, Indonesia \\ ${ }^{*}$ Corresponding author. Email: berta.putri@fp.unila.ac.id
}

\begin{abstract}
Research on the characteristics of distribution of phosphate, nitrate and Chlorophyll-a have been carried out in Pulau Pasaran waters Lampung from May to July 2017. The aim of this research was to determine the nutrient distribution and tropic status of Pulau Pasaran waters by chlorophyll-a, nitrate, and orthophosphate, ammonia, salinity, dissolved oxygen, $\mathrm{pH}$ and transparency. Sampling was done by using purposive sampling method in five stations around the coastal waters of Pulau Pasaran. The water samples were analyzed at the Research Centerof Marine Aquaculture (BBPBL) Lampung. The tropic status of Pulau Pasaran waters was characterizes using Principal Component Analysis (PCA) by software Past13 and Surfer14. The results indicate that waters of Pulau Pasaran are classified as eutrophic which is the concentration of nitrates and orthophosphates was positively correlated with the concentration of chlorophyll-a.
\end{abstract}

Keywords: chlorophyll-a, nutrient, nitrate, orthophosphate, Pulau Pasaran

\section{INTRODUCTION}

Tropic Status generally associated with nutrient concentrations in waters. High-low chlorophyll content-a very closely related to the supply of nutrients derived from land through the river flow into the waters. Nitrates and orthophosphates are nutrients that can be utilized directly by phytoplankton, where the concentration of phytoplankton is closely related to water productivity although the densities is influenced by both intrinsic and external factors $[1,2]$.

Phosphate and nitrates are very important for their presence. However, if the concentration is too high it can cause blooming that has a negative impact on other water biota. The concentration of chlorophyll-a and nutrients will increase if approaching the coastal area and will decrease when approaching the open sea. This is due to the increasing number of nutrient inputs in the coastal areas and the fewer as it approaches the high seas, due to the further distance with onshore activities [3].

Pulau Pasaran are being subjected to increasing anthropogenic stresses such as aquaculture in floatingcage, fishing, home industry, ship traffic, traditional markets, and other activities which are affecting coastalwater quality $[4,5]$. The high activity in that island can be a source of nutrients in the water such as nitrate and phosphate. The concentration of nitrate and phosphate will affect the concentration of chlorophyll-a and the tropic state in waters.
When the tropic state in waters belongs to the eutrophic category, it can be potentially occurrence of blooming algae that can be harmful for marine life and also for human [2].

The main objective of this research was to determine the tropic state of Pulau Pasaran waters by chlorophyll-a, nitrate, and orthophosphate.

\section{MATERIALS AND METHODS}

\subsection{Sampling}

The research was conducted in Pulau Pasaran, Bandar Lampung, from May to July 2017. Sampling was conducted every month in 5 observation stations around the coastal waters of Pulau Pasaran. First, Station A is located at the mouth of the River Way Belau, this river estuary is also used as a new dock for fishing boats on the island. The B station is located in the waters of the mangrove area. These waters are located in the north of the island. Cungkeng fish is located of the C Station, it's port which is still often used by the local community. Station D is located in the waters around floating net cages (KJA) to the west of island. The E station is located in the southeast of Pulau Pasaran, this station is facing the Open area. The research location maps, and coordinates of the observation stations are presented in Figure 1. 


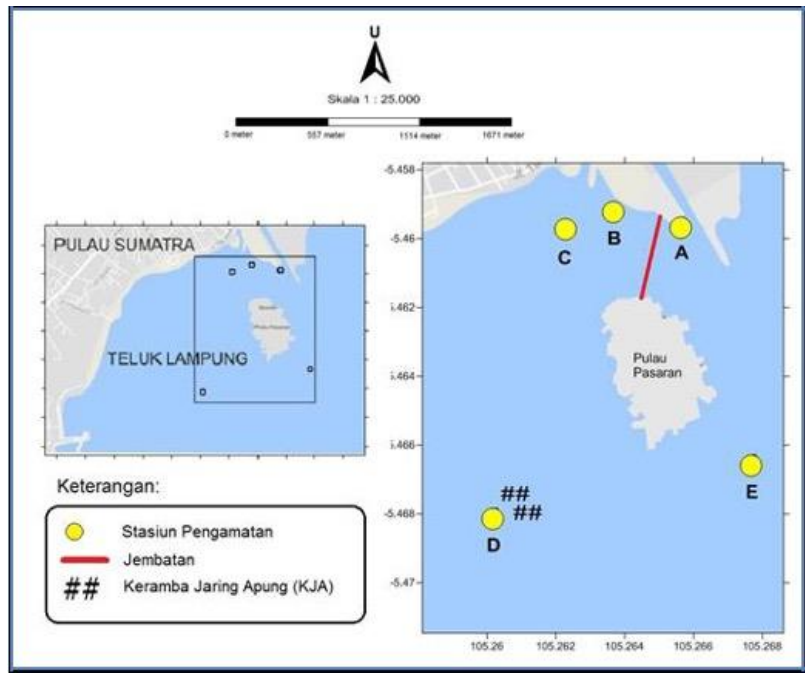

Figure 1 Research location and the observation station

\subsection{Research Method}

This research used the descriptive method using purposive sampling. Water samples were collected in 500 $\mathrm{ml}$ sample containers, stored on ice and transported to the laboratory for filtration and preservation.

The parameter nitrate, phosphate, ammonia and chlorophyll-a were analyzed at the Research Center of Marine Aquaculture (BBPBL) Lampung [6]. Whereas for temperature, salinity, $\mathrm{pH}$, transparency, and water current measured in situ.

\subsection{Data Analysis}

The data (chlorophyll-a, nitrate and orthophosphate at each station) are then distributed by using Surfer14, i.e., by using interpolation to parameter values contained in each station. The interpolation results are then presented in a horizontal contour form, which is then stacked into the coastal map of Pulau Pasaran. The number of contours made as many as 5 pieces, according to the number of sampling. Principal Component Analysis (PCA) was used to determine the relationship between station grouping parameters based on physics-chemical variables of aquatic [7]. The main component analysis is a multivariate statistical analysis approach that can be used to interpret the measurement results of related using Past13 software.

\section{RESULT AND DISCUSSION}

\subsection{Distribution of Chlorophyll-a, Nitrate, and Orthophosphate}

Based on the measurement of chlorophyll-a in May 2017 it was found that the lowest chlorophyll-a value of $0.099 \mathrm{mg} / \mathrm{l}$ was found in station $\mathrm{B}$, and the highest concentration of $0.150 \mathrm{mg} / 1$ was found at station C. Station $\mathrm{B}$ was a station located near mangroves under conditions low currents ranging from $5-7 \mathrm{~m} / \mathrm{dt}$ to allow the least process of nutrient stirring in the water. In addition, the waters at station B are by passed by fishing vessels, allowing at least nutrient input to affect chlorophyll-a at the station. The $\mathrm{C}$ station is located around the fishing boat port so it is assumed that many nutrients enter the waters and become one of the factors causing the high concentration of chlorophyll-a at the station. According to [8], the port becomes a station with a high concentration of chlorophyll-a due to the abundance of activity in the place so that it can cause the entry of organic materials into the waters such as food scraps. The results of chlorophyll-a, nitrate and orthophosphate concentration analysis are presented in Figure 2.

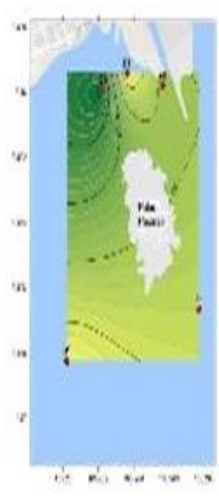

May

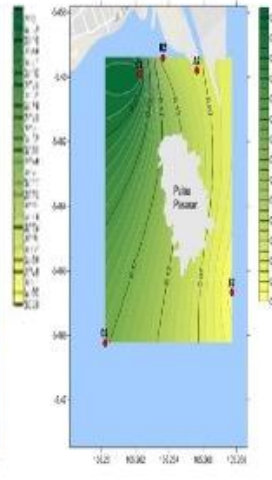

Jule

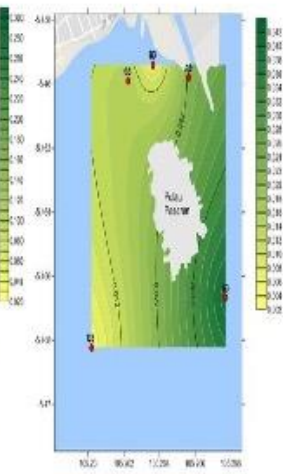

July
Figure 2 Distribution of chlorophyll-a in Pulau Pasaran Waters from May to July 2017.

In the June observation, the lowest concentration of chlorophyll-a was at station E, of $0.024 \mathrm{~m} / 1$. This is presumably because the location of station $\mathrm{E}$ which is farther from mainland (Sumatera Island) compared to other stations, so the possibility of nutrient input from coastal area and river stream will be less. The highest concentration of chlorophyll-a is at station C, of 0.300 $\mathrm{mg} / \mathrm{l}$. Station $\mathrm{C}$ is located around the fishing boat port and approached the settlement, so it is suspected that high nutrient input and cause the high concentration of chlorophyll-a at the site. The highest concentration of orthophosphate in June was at C station with a value of $1.262 \mathrm{mg} / \mathrm{l}$. This becomes one of the factors causing high chlorophyll-a at $\mathrm{C}$ station.

On chlorophyll-a observation in July 2017, the lowest concentration of chlorophyll-a was located at station D located around the floating net cages (KJA) belonging to the population of Pulau Pasaran, with a chlorophyll-a concentration of $0.004 \mathrm{mg} / \mathrm{l}$. The low concentration of chlorophyll-a at station D is followed by a low orthophosphate concentration also with a value of 0.467 $\mathrm{mg} / \mathrm{l}$. The highest concentration of chlorophyll-a was at station $\mathrm{E}$ with a concentration of $0.041 \mathrm{mg} / \mathrm{l}$. This followed a high orthophosphate concentration of 0.985 $\mathrm{mg} / \mathrm{l}$. This condition is consistent with [9] statement that orthophosphate is a form of phosphate utilized directly by 
aquatic plants, so when orthophosphate is high it is assumed the chlorophyll also high.

Nitrate concentration in the waters of Pulau Pasaran in May ranged from 0.874 to $1.616 \mathrm{mg} / \mathrm{l}$. The highest concentration nitrate distribution in May was located at station $\mathrm{C}$ located in the waters around Pier Cungkeng, with a concentration of 1.616. mg/l (Figure 3). The lowest nitrate concentration with a value of $0.874 \mathrm{mg} / \mathrm{l}$ is located at station D located in the vicinity of floating net cages and away from beaches or residential areas. This is in accordance with the opinion of [10] states that the concentration of nitrate will be lower when away from the mainland because the supply of organic material is reduced.

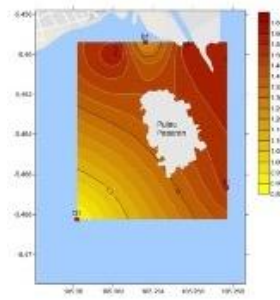

May

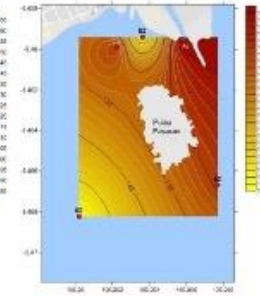

June

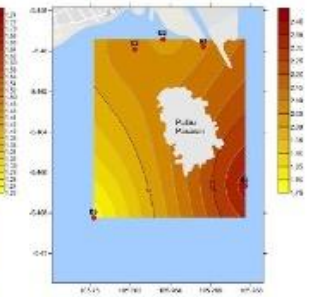

July
Figure 3 Distribution of nitrate in Pulau Pasaran Waters from May to July 2017

The highest nitrate concentration in June was at station A with a value of $1.728 \mathrm{mg} / \mathrm{l}$. This concentration can be due to the location of station A located at the mouth of the River Way Belau, so that nutrients will be carried by the river flow and accumulate in the waters of the estuary. The lowest concentration with a value of $1.228 \mathrm{mg} / \mathrm{l}$ is located at station $\mathrm{D}$ which is around the floating net cages and away from the settlement.

In July, the highest nitrate concentration of $2.380 \mathrm{mg} / \mathrm{l}$ was at station $\mathrm{E}$ which lies slightly near the sea. When compared with other stations, the strong currents in station E include higher ranging from $10-13 \mathrm{~cm} / \mathrm{sec}$. It is suspected to affect the level of nutrient stirring in the waters so that the concentration of nitrate at station $\mathrm{E}$ is high. The lowest nitrate concentration of $1.757 \mathrm{mg} / \mathrm{l}$ is located at station D located around the floating net cages and away from the shore. The current strength at station $\mathrm{D}$ is low with values ranging from $4-7 \mathrm{~cm} / \mathrm{sec}$. This can cause a low nutrient stirring at the station and that it is suspected to be the cause of low nitrate at the station. According to [10], nitrogen in inorganic form useful for plants is nitrate, nitrites, and ammonia. The process of overhauling materials containing nitrogen in rocks is done by microorganisms. Nitrogen is converted from amino-nitrogen (R-NH2) to ammonium $\left(\mathrm{NH}_{4}^{+}\right)$, then to nitrite (NO2) and then to nitrate (NO3). In natural conditions, nitrate levels almost never exceed 0.1 $\mathrm{mg} / \mathrm{l}$. If nitrate levels greater than $5 \mathrm{mg} / \mathrm{l}$ indicate anthropogenic contamination from human activities and animal feces. In addition, the concentration of nitrate can be used for grouping the water fertility rate. Nitrate concentrations between $0-1 \mathrm{mg} /$ liter include the oligotrophic waters category, $1-5 \mathrm{mg} / \mathrm{l}$ concentrations belonging to mesotrophic waters, and $5-50 \mathrm{mg} / \mathrm{l}$ belonging to eutrophic waters [11].

The concentration of nitrate in the waters of Pulau Pasaran which ranges from $0.874-2.380 \mathrm{mg} / \mathrm{l}$ indicates that the waters of are categorized as oligotrophic and mesotrophic waters based on [11]. However, according to [9], nitrate concentrations greater than $0.2 \mathrm{mg} / \mathrm{liter}$ can cause eutrophication (enrichment) of the waters, and will lead to blooming algae. Therefore, based on the results of nitrate measurements it can be ascertained that around the waters of the Pulau Pasaran of the market the chance of eutrophication. According to [9], oligotrophic waters are waters with low nutrients and productivity, while mesotrophic waters with nutrients and moderate productivity. The mesotrophic waters are a transition between oligotrophic and eutrophic. Based on [12], the nitrate quality standard for marine biota is $0,008 \mathrm{mg} / \mathrm{l}$. Therefore, the content of nitrate in the waters of the Pulau Pasaran ranged from 0.874 to $2.380 \mathrm{mg} / \mathrm{l}$, it is included in the category that is not suitable for marine biota.

The concentrations of orthophosphate in May ranged from $0.309-0.487 \mathrm{mg} / \mathrm{l}$. The highest concentration was at station D $(0.487 \mathrm{mg} / \mathrm{l})$. According to [9] sources of phosphorus in the waters can be derived from weathering of mineral rocks and anthropogenic activities such as industrial and domestic waste. The high concentration of orthophosphate at station D may be derived from anthropogenic activities such as fish processing in Pulau Pasaran whose wastes can be brought into the waters at station D. Besides that, around the D station there is also fish farming activity (KJA) which has the potential to produce organic waste. The lowest concentration is at station $\mathrm{C}$ with a value of $0.309 \mathrm{mg} / \mathrm{l}$. The concentration is not much different from station $\mathrm{D}$. The location of station $\mathrm{C}$ located in the waters of Cungkeng Pier and adjacent to the settlement is thought to be a factor influencing the high concentration of orthophosphate.

The highest orthophosphate concentration in June was at the $\mathrm{C}$ station located in the vicinity of Cungkeng Pier, with a concentration value of $1.262 \mathrm{mg} / \mathrm{l}$. It can be influenced by anthropogenic activities around the $\mathrm{C}$ station located in the waters of Cungkeng Pier. The lowest concentration of orthophosphate is located at station B which is located in the waters around mangrove area overgrown with concentration value of $0.475 \mathrm{mg} / \mathrm{l}$. At the station the orthophosphate concentration also includes high (eutrophic) which can be caused by the presence of mangrove vegetation in the area. The overgrown waters can trap sediments from the land including sediments containing phosphate elements. In addition, the area around the mangrove can also supply amounts of nutrients to the litter of prairie originating from mangrove. 


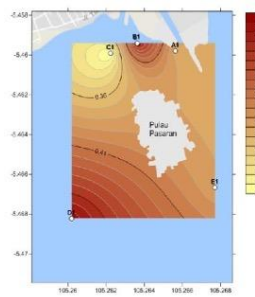

May

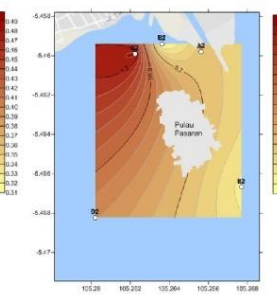

June

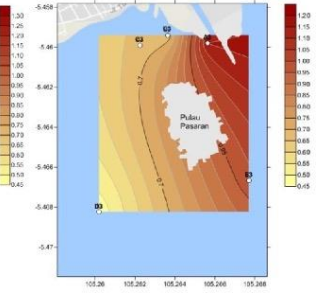

July
Figure 4 Distribution of orthophosphate in Pulau Pasaran Waters from May to July 2017

The highest orthophosphate concentration in July was at station A located at the estuary h of the Way Belau River, with the concentration of $1.151 \mathrm{mg} / \mathrm{l}$. The accumulation of nutrients in the estuary from the river leads to high concentrations of orthophosphates at the station. In addition, station $\mathrm{A}$ is also waters close to the new pier of Pulau Pasaran so that high fishing activity can be a source of orthophosphate input in the waters. The lowest orthophosphate concentration was at station $\mathrm{D}$ with a value of $0.467 \mathrm{mg} / \mathrm{l}$ (Figure 4). However, the concentration is still categorized as high. According to Wetzel (1975), based on orthophosphate levels, water is classified into three (Table 1).

Table 1. Water Trophic State [11]

\begin{tabular}{|c|c|}
\hline Orthophosphate $(\mathbf{m g} / \mathbf{l})$ & Trophic State \\
\hline $0,003-0,01$ & Oligotrophic \\
\hline $0,011-0,03$ & Mesotrophic \\
\hline $0,031-0,1$ & Eutrophic \\
\hline
\end{tabular}

Concentrations of orthophosphates in the waters of Pulau Pasaran ranging from 0.309 to $1.262 \mathrm{mg} / \mathrm{l}$ indicate that the waters of Pasar Pulau belong to the eutrophic category according to [11]. Eutrophic waters are waters with high nutrient content and have low brightness and dissolved oxygen content [9]. Such a condition could potentially bloom the algae which could lead to mass mortality of fish, both in nature and cultivated fish. Based on these reasons, it can be said that the market of Pasuruan Island is less suitable for marine biota. This was confirmed by [12], that the appropriate phosphate concentration for marine biota was $0.015 \mathrm{mg} / \mathrm{l}$.

In this study, most waters close to the mainland have high nutrient content (nitrate and orthophosphate) followed by high chlorophyll-a concentrations. As for waters far from land, the nutrient content is low and followed by low chlorophyll-a concentration. Nutrients (nitrates and orthophosphates) derived from land or run off, thus contributing very important to chlorophyll-a in the waters of the island market.

Based on the literature, the waters of Pulau Pasaran which have a concentration of chlorophyll-a $\geq 0,004-0,30$ $\mathrm{mg} / \mathrm{l}$ (or equivalent to $\geq 4-300 \mu \mathrm{g} / \mathrm{l}$ ) can be categorized into eutrophic waters. The concentration of a-chlorophyll in the waters of Pulau Pasaran, ranging from $\geq 0,004-0,30$ $\mathrm{mg} / \mathrm{l}$ (or equivalent to $\geq 4-300 \mu \mathrm{g} / \mathrm{l}$ ) indicates that the waters can be categorized into eutrophic waters.

Based on the research that has been done and reviewed through the concentration of chlorophyll-a, nitrate and orthophosphate, Pulau Pasaran waters is included in the category of eutrophic waters. These conditions can potentially lead to eutrophication. In the event that eutrophication of algae abundance is dominated by algae species categorized as the cause of harmful alga blooming (HAB) then the condition can be dangerous because it can cause harm to society.

The phenomenon of $\mathrm{HAB}$ has a negative impact on the sustainability of coastal ecosystems, capture fisheries, cultivation industry, and even endanger human [13]. HAB also have a negative impact on the economy because it can lead to deaths in fishery biota that make the biota price is not valuable, increase monitoring costs to a water, and can disrupt tourism activities in these waters [14].

Based on [15] that conducted at Pantai Ringgung, Lampung Bay, it can be seen that the increasing abundance of dangerous phytoplankton will be followed by the increase of mortality rate of fish. This occured on June 19, 2013, where there is a potential explosion of phytoplankton populations of HAB (highest type of Cochlodinium reaches 63,738 cells per liter) and caused the death of fish reached 20 individual at Floating net Cage in Pantai Ringgung, Lampung Bay.

\subsection{The Relationship Between Chlorophyll-a Concentration and Other Parameters.}

Principal component analysis (PCA) was used to determine the relationship between chlorophyll-a concentration and other parameters (Table 2). Analysis of the main components can group the parameters so that the parameters are mutually correlated. Some other parameters used in this analysis are nitrate, orthophosphate, ammonia, chlorophyll-a, temperature, salinity, DO, $\mathrm{pH}$, and current.

Table 2. Variance Diversity of Principal Component Data

\begin{tabular}{|c|c|c|c|}
\hline Component & $\begin{array}{l}\text { Eigen } \\
\text { Value }\end{array}$ & $\begin{array}{c}\text { Variance } \\
(\boldsymbol{\%})\end{array}$ & $\begin{array}{c}\text { Cumulative } \\
(\boldsymbol{\%})\end{array}$ \\
\hline 1 & 2.85276 & 31.697 & 31.697 \\
\hline 2 & 1.7302 & 19.224 & 50.921 \\
\hline
\end{tabular}

Chlorophyll-a is positively associated with nitrate and orthophosphate. Ammonia, DO, pH, and temperature show a negative relationship (Figure 5). Nitrate is the main form of nitrogen in the waters and is a major nutrient needed by plants and algae [9]. Therefore, nitrate and chlorophyll a will be negatively related and shown by a one-way line where when the nitrate concentration of a high water then the concentration of chlorophyll-a will be high. According to [9], orthophosphate is a form of 
phosphorus that can be exploited by aquatic plants. Based on this statement, the chlorophyll-a and orthophosphate are positively related where, if the orthophosphate concentration is high, it will be followed by high chlorophyll-a concentration.

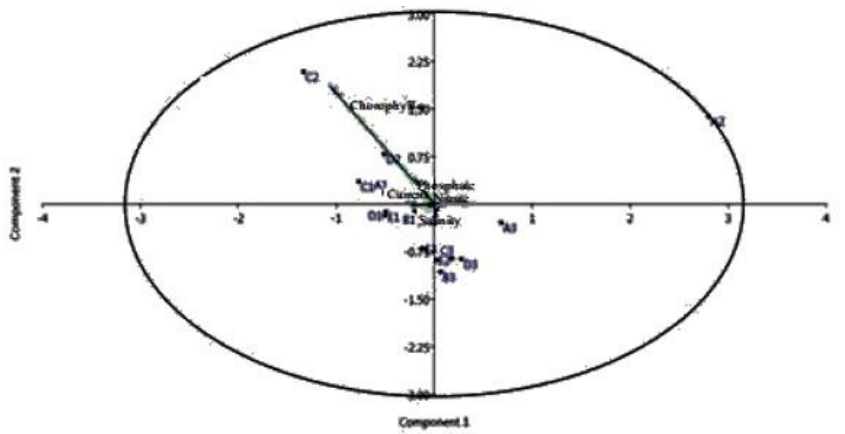

A1: Station A sampling (May) A2: Station A sampling (June) A3: Station A sampling (July) B1: Station B sampling (May) B2: Station B sampling (June) B3: Station B sampling (July) C1: Station C sampling (May) C2: Station C sampling (June) C3: Station C sampling (July)

Figure 5 Plot curve between axis parameter 1 and parameter axis 2

Station A (in May), station C (in May, June) and D (in May) are characterized by high chlorophyll-a, nitrate and orthophosphate. Thus, in those months at the station, $\mathrm{C}$ and $\mathrm{D}$ may be blooming algae. According to [7], the relationship between parameters can also be seen from the angle formed by the parameter line on the biplot curve. If the angle value formed from 2 parameters $<90^{\circ}$, then the relationship of two parameters is positive or affect each other. However, if the angle is formed $>90^{\circ}$, then the relationship will be inversely proportional. As if the angle formed equal to $90^{\circ}$ then there is no significant relationship between the two parameters.

\section{CONCLUSION}

Based on the research that has been done can be concluded that based on the concentration of chlorophylla, nitrate and orthophosphate, Pulau Pasaran waters belong to eutrophic category and potentially cause algae to eutrophic category and potentially cause algae blooming.

\section{ACKNOWLEDGMENTS}

1. DRPM Kemenristekdikti

2. Research Center and Community Services, University of Lampung

3. Fisheries and Marine Science Department, Agriculture Faculty University of Lampung

4. Aquaculture Department, State Polytechnic of Lampung

\section{REFERENCES}

[1] Karydis, M. Eutrophication assessment of coastal waters based on indicators: A literature review. 2009. Global NEST Journal, pp. 373-390. https://DOI:10.30955/gnj.000626

[2] Kitsiou D. and Karydis M. Development of categorical mapping for quantitative assessment of eutrophication, Journal of Coastal Conservation, 1998. pp, 33-44.

[3] Ayuningsih, M.S., Hendrarto, B and Purnomo, PW. Distribusi kelimpahan fitoplankton dan klorofil-a di Teluk Sekumbu Kabupaten Jepara: hubungannya dengan kandungan nitrat dan fosfat di perairan. Diponegoro Journal of Maquares. 2014.3,pp.138147. https://DOI.org/10.14710/marj.v3i2.5017

[4] Berta Putri, Nuning Mahmudah Noor dan Mahrus Ali. Pembinaan Usaha Budidaya Kerang Hijau dan Ikan di Pulau Pasaran, Lampung. 2017. Jurnal Sakai Sambayan 2.1. pp 30-35. DOI:10.23960/jss.v2i1.50

[5] Noor, N.M. 2015. Prospek Pengembangan Usaha Budidaya Kerang Hijau di Perairan Pulau Pasaran, Kota Bandar Lampung. Aquasains. 3.3. pp 397-412

[6] Andrew D Eaton; Lenore S Clesceri; Arnold EGreenberg; Mary Ann H Franson; American Public Health Association, 1998, Standard Methods for the Examination of Water and Waste Water. $4500-\mathrm{NO}_{2}$, $20^{\text {th }}$ Edition. Washington DC: APHA, AWWA, WEF.

[7] Mahapatra, Mrutyunjaya Sahu, R.K. Patel and Biranchi Narayan Panda. Prediction of Water Quality Using Principal Component Analysis. Water Qual Expo Health. 2012. 4. pp:93-104.DOI: 10.1007/s12403-012-0068-9

[8] Lars Håkanson and Jenny M Eklund. 2010. Relationships Between Chlorophyll, Salinity, Phosphorus, and Nitrogen in Lakes and Marine Areas. Journall of Coastal Research 26(3) pp: 412 423 DOI: $10.2112 / 08-1121.1$

[9] Effendi, H. 2003. Telaah kualitas air bagi pengelolaan sumberdaya dan lingkungan perairan.Kanisius. Yogyakarta. pp. 258.

[10] Ishak. 2010. Distribusi fosfat, nitrat, derajat keasaman, dan oksigen terlarut di perairan Belitung.Buku Monograf. LIPI Press. Jakarta. pp. 236-247.

[11] Reynolds, C.S. 1984. The ecology of freshwater phytoplankton. Cambridge University Press.Cambridge.pp 384.

[12] KMNLH. 2004. Surat Keputusan Menteri Negara Kependudukan dan Lingkungan hidup No.51/MENKLH/2004 tanggal 6 April 2004: pp 5. 
[13] Anderson, D.M. Approaches to monitoring, control and management of harmful algae blooms (HABs). Ocean coastal management. 2009. 52 (7), pp. 342347. https://DOI: 10.1016/j.ocecoaman.2009.04.006.

[14] Hoagland, P., Jin, D., Beet, A., Kirkpatrick, B., Reich, A., Ullmann, S., Fleming, L., The human health effects of Florida Red Tide (FRT) blooms: An expanded analysis. Environmental international.
2014. 68, pp 144-153. https://DOI: 10.1016/j.envint.2014.03.016.

[15] Irawan, Ade., Hasani, Qadar, and Yulianto, Herman. Phenomenon of Harmful Algal Blooms (HABs) in Ringgung Beach-Lampung Bay, Influence for Fish Mortality on Cage Culture.Jurnal Penelitian Pertanian Terapan. 2014. (1) pp. 48-53.https://DOI: 10.25181/jppt.v15i1.111. 